\title{
Tratamento do pé varo espástico através da hemitransposição do tendão do tibial posterior
}

\author{
Split tibials posterior tendon transfer in the management of spastic talipes varus
}

\author{
Ana Paula T. Gabrieli' Helena Elisa Stein², Lauro Machado Neto ${ }^{3}$
}

\section{RESUMO}

Foram avaliados dez pacientes (12 pés) com paralisia cerebral espástica submetidos à hemitransposição do tendão do tibial posterior para correção da deformidade em varo do pé. Quatro pacientes eram do sexo feminino e 6 do sexo masculino. A idade média dos pacientes foi de 8 anos e 9 meses. Seis pacientes apresentavam paralisia cerebral espástica hemiplégica; 2,diplégica e 2 pacientes, paralisia cerebral tipo misto. $\mathrm{O}$ tempo médio de seguimento foi de 26 meses. Cirurgias associadas foram realizadas em 11 pés (92\%). Oito pés apresentaram bom resultado (67\%), três pés (25\%), resultado regular e um pé (8\%), mau resultado. Nenhum dos pés desenvolveu deformidade em calcâneo-valgo. Os resultados regulares e mau estiveram associados principalmente à insuficiência do músculo tibial anterior que levou à necessidade de manutenção do uso de órtese no pós-operatório, à influência de outras forças deformantes no pé além do músculo tibial posterior e à presença de deformidade óssea estruturada. Os autores concluem que a técnica de hemitransposição do tendão do tibial posterior, associada a outras cirurgias quando necessário, tem bom resultado na correção da deformidade em varo do pé na paralisia cerebral; desde que sejam determinadas corretamente as características dinâmicas da deformidade e eventuais deformidades associadas sejam tratadas de forma apropriada, concomitantemente.

Descritores: Paralisia cerebral; Pé varo; Espasticidade muscular

\section{SUMMARY}

Ten patients with cerebral palsy and varus spastic deformity (12 feet) were evaluated after hemitransposition of posterior tibial tendon. There were 4 female and 6 male patients. Mean age at surgery was 8 years and 9 months. Regarding motor involvement, 6 patients were hemiplegic, 2, diplegic and 2 patients had mixed type cerebral palsy. Mean follow-up was 26 months. Associated surgeries were performed in 92\% of the cases (11 feet). Good results were achieved in $67 \%$ of the cases and regular results in $25 \%$. There was one bad result (8\%). None of the feet developed a calcaneovalgus deformity. Regular and bad results were mainly associated to anterior tibial insufficiency, leading to the maintenance of the orthosis; the influence of other deforming forces on the foot besides the posterior tibial and to the presence of structural bony deformities. The technique of hemitransposition of tibial posterior tendon, associated to other procedures as indicated, leads to good results in correcting spastic varus deformity of the foot in cerebral palsy. Dynamic components of the deformity need to be determined pre-operatively and structural bony deformities must be corrected concomitantly.

Keywords: Cerebral palsy; Varus foot; Muscle Spasticity.
Trabalho realizado na Universidade de Caxias do Sul, Departamento de Clínica Cirúrgica do Centro de Ciências Biológicas e da Saúde, disciplina de Ortopedia e Traumatologia

1. Mestre em Ortopedia e Traumatologia, Professora titular da disciplina de Ortopedia e Traumatologia da Universidade de Caxias do Sul

2. Doutoranda da Universidade de Caxias do Sul

3. Ortopedista e Traumatologista, Diretor do Corpo Clínico da AACD / RS

Endereço para correspondência: R. Gal. Arcy da Rocha Nóbrega, 401 / 703 Caxias do Sul - RS - CEP 95040-290 - e-mail: gabrieli@terra.com.br
Work performed at the University of Caxias do Sul, Department of Surgical Clinics of Center of Biological Sciences and Health , Orthopedics and Traumatology.

1. Master in Orthopedics and Traumatology, Professor of Orthopedics and Traumatology at the University of Caxias do Sul

2. Doctorate Student at the Univesity of Caxias do Sul

3. Orthopedist and Traumatologist

Address: R. Gal. Arcy da Rocha Nóbrega, 401 / 703

95040-290 Caxias do Sul RS

e-mail: gabrieli@terra.com.br 


\section{INTRODUÇÃO}

As deformidades em eqüino, valgo e varo do pé são freqüentes nos pacientes com paralisia cerebral (PC). A deformidade em varo do pé é bem menos comum que em valgo e mais freqüente nos hemiplégicos. O desequilíbrio da dinâmica entre músculos tibial posterior e flexor dos dedos (espásticos) e os músculos fibulares, gera a deformidade em varo, à qual freqüentemente associa-se o eqüino ${ }^{(5,7)}$. A deformidade em varo do pé interfere no apoio e na marcha, alterando os mecanismos das fases de apoio e balanço do ciclo, não só no pé e tornozelo, mas também no joelho e quadril (4). Além disso, freqüentemente ocorrem dificuldades com o uso de sapatos e órteses e aparecimento de dor e calosidades nas áreas de pressão ${ }^{(13,14)}$

O músculo tibial posterior é o principal causador do varismo dinâmico durante a marcha ${ }^{(5)}$. Através do exame físico cuidadoso, incluindo um teste muscular, pode-se diferenciar a contribuição dos músculos tibial posterior e anterior na gênese da deformidade. A presença de anormalidades ósseas estruturadas também deve ser notada, pois a deformidade em varo pode ser dinâmica, evidenciada somente na marcha, tanto na fase de apoio como na de balanço, sendo possível durante o exame físico a correção da adução e do eqüino do pé, ou fixa, notada tanto no repouso como durante a marcha. Inicialmente o tratamento desta deformidade baseia-se em exercícios de alongamento da musculatura e uso de órteses. O tratamento focal da espasticidade do músculo tibial posterior através da aplicação de toxina botulínica A também tem sido utilizada. A terapêutica cirúrgica está indicada na falha do tratamento conservador ${ }^{(9,14)}$.

No arsenal cirúrgico para o tratamento da deformidade em varo do pé espástico encontram-se várias técnicas. A tenotomia do tibial posterior na sua inserção no navicular, relacionase freqüentemente ao colapso da articulação talonavicular, com resultante deformidade em valgo do retropé(1). O alongamento intramural ou do tendão do tibial posterior, causa o enfraquecimento muscular, mas não promove o redirecionamento das forças anômalas atuantes no pé, teoricamente favorecendo recorrências da deformidade. As técnicas de redirecionamento do tendão do tibial posterior anteriormente no maléolo medial e a transposição de todo ou metade do tendão do tibial posterior através da membrana interóssea para o dorso do pé mostram resultados inconsistentes ${ }^{(1,2,8,10,11)}$

A hemitransposição do tendão do tibial posterior para o tendão do fíbular curto na correção da deformidade em varo dos pés de pacientes com PC foi primeiramente descrita por Green ${ }^{(5)}$, que recomenda o uso da técnica quando o músculo tibial posterior é espástico, o músculo tibial anterior é fraco e os fibulares fracos ou ausentes. Com o tratamento cirúrgico, no qual o retropé é equilibrado sem o enfraquecimento excessivo do músculo tibial posterior, objetiva-se produzir e manter um pé plantígrado, prevenir deformidades esqueléticas e possibilitar ou meIhorar a marcha. Outros autores demonstraram bons resultados com a técnica $(3,6,7,8,11,14)$.

Este estudo descreve e avalia os resultados de 10 pacientes (12 pés) que receberam tratamento do pé varo espástico através da hemitransposição do tendão do tibial posterior pela técnica de Green.
Equinus, valgus, and varus talipes are frequently found in patients with cerebral palsy (CP). Varus talipes is much rarer than valgus talipes and more frequent in hemiplegic patients. Imbalance in the dynamics between the tibialis posterior and toe flexor muscles (spastic) and peroneus muscles leads to varus talipes, often associated with equinus talipes ${ }^{[5,7]}$. Varus talipes adversely affects support and gait by modifying the mechanisms of support and cycle balance phases not only of the foot and ankle, but also of the knee joint and hip ${ }^{[4]}$. In addition, the use of shoes and orthoses is difficult, pain and callosities develop in areas under pressure [13, 14].

The tibialis posterior muscle is the main muscle involved in dynamic varus abnormality during gait ${ }^{[5]}$. Careful physical examination, including muscular tests, can distinguish the participation of the tibialis posterior muscle from that of the tibialis anterior muscle in the causation of deformity. Associated structured bone abnormalities must also be investigated since varus deformity can be dynamic and evidenced during walking only, appearing during the support and/or the balance phase. Physical examination can reveal correction of adduction and talipes equinus at rest and during walking. Initial treatment for this deformity is based upon lengthening exercises and use of orthosis while focal treatment for spasticity of tibialis posterior muscle with type $A$ botulinum toxin has also been used. Surgical therapy is indicated when conservative therapy fails ${ }^{[9,14]}$.

Several techniques are used in the management of spastic talipes varus. Tenectomy of the tibialis posterior muscle at its insertion on the navicular bone is frequently associated with talonavicular joint collapse, resulting in hindfoot valgus ${ }^{[1]}$. Intramural or tibialis posterior muscle lengthening leads to muscular weakening but do not enhance redirection of anomalous forces acting upon the foot, theoretically favoring deformity recurrence. Techniques of anterior redirection of the tibialis posterior tendon on the medial malleolus and total or partial transposition of the tibialis posterior tendon through interosseous membrane to the back of the foot have been associated with inconsistent results $[1,2,8,10,11]$.

Split tibialis posterior tendon transfer to the peroneus brevis tendon was first described by Green ${ }^{[5]}$ for correction of talipes varus in patients with CP. This author recommends the use of this technique when the tibialis posterior muscle is spastic, the tibialis anterior muscle is weak, and peroneus muscles are weak or lacking. Surgical treatment aims to produce and maintain a platigrade foot, prevent skeletal deformities, and make walking possible or improve it. With surgery hindfoot is balanced without the excessive weakening of the tibialis posterior muscle. Other authors have obtained good results with the technique ${ }^{[3,6,7,8,11,14]}$.

The present study describes and evaluates the results obtained in 10 patients (12 feet) in whom spastic talipes varus was treated with split tibialis posterior tendon transfer according to the technique described by Green. 


\section{MATERIAIS E MÉTODOS}

Foram revisados prontuários de cirurgias realizadas no período de julho de 1996 a junho de 2001, onde 10 pacientes, todos deambuladores comunitários (12 pés), portadores de PC espástica com deformidade em varo foram submetidos à hemitransposição do tendão do tibial posterior. Seis pacientes eram do sexo masculino e 4 do feminino. A média de idade dos pacientes foi de 8 anos e 9 meses, variando de 4 anos e 2 meses a 16 anos. Oito pacientes (80\%) apresentavam deformidade unilateral e 2 (20\%), deformidade bilateral.

Quanto ao tipo de PC, 6 (60\%) eram do tipo espástico hemiplégico; 2 (20\%) espástico diplégico e 2 (20\%) eram do tipo diplégico misto ( componente atetóide ou distônico). Nove pés apresentavam deformidade em eqüino associada. Oito pés apresentavam deformidade em varo dinâmica e 4 pés, deformidade estruturada em varo. Quatro pés apresentavam também deformidade em cavo, com teste de Coleman positivo.

O tempo médio de acompanhamento pós-operatório foi de 26,6 meses, variando entre 12 e 67 meses.

Todos os pacientes realizaram tratamento conservador da deformidade preliminarmente à cirurgia (fisioterapia, uso de órteses, aplicação de toxina botulínica), sendo a mesma posteriormente indicada devido à falha do tratamento. A indicação cirúrgica foi baseada no exame físico, com a deformidade em varo apresentando-se durante todo o ciclo da marcha, bem como na presença de calosidades na borda lateral do pé e anormalidade do calçado. Estudos eletromiográficos ou análise de marcha não foram realizados.

Os procedimentos foram realizados por dois cirurgiões diferentes, seguindo a técnica descrita por Green ${ }^{(5)}$.

Cirurgias associadas foram realizadas conforme a necessidade de cada caso dependendo do tipo das deformidades associadas encontradas.

Por tratar-se de um estudo retrospectivo, onde somente os prontuários dos pacientes foram examinados, não houve necessidade de consentimento informado para a elaboração deste trabalho.

\section{RESULTADOS}

Os resultados foram avaliados baseando-se em critérios clínicos de correção da deformidade em varo e necessidade do uso de órteses no período pós-operatório.

Os casos considerados como tendo bons resultados foram os que tiveram a deformidade corrigida e não necessitaram do uso de órteses. Resultados regulares foram aqueles que apesar da correção, necessitaram do uso de órteses (goteira de polipropileno) para a marcha. Maus resultados apresentaram deformidade residual com necessidade de correção cirúrgica subsequente. Bons resultados foram obtidos em $67 \%$ dos casos ( 8 pés -7 pacientes). Três pés (2 pacientes obtiveram resultados regulares (25\%), e 1 pé, mau resultado (8\%). Não houve complicações cirúrgicas (Tabela 1).

O caso de mau resultado apresentava outras forças deformantes no membro inferior além do músculo tibial posterior, que contribuíam para a alteração da marcha, além de varo estrutu-

\section{MATERIALS AND METHODS}

Medical records of patients operated from July 1996 to June 2001 were reviewed. Six male and 4 female community ambulatory patients with spastic cerebral palsy and talipes varus (10 patients with a total of 12 feet) were submitted to split tibialis posterior tendon transfer. Patients were aged 4 years and 2 months to 16 years (mean age: 8 years and 9 months). Unilateral deformity was present in 8 (80\%) patients and bilateral deformity was found in 2 (20\%) patients.

As for the type of CP, 6 (60\%) were of the spastic hemiplegic type; 2 (20\%) were of the spastic diplegic type; and 2 (20\%) were of the mixed diplegic type (athetotic or dystonic component). Talipes varus and equinus were associated in nine feet. Dynamic varus deformity was present in 8 feet and structured varus deformity was found in 4 feet. Talipes cavus was also present in four feet with a positive Coleman test.

Postoperative follow-up ranged from 12 to 67 months with a mean of 26.6 months.

Conservative treatment was used by all patients before surgery, including physical therapy, use of orthoses, type-A botulinum toxin. Surgery was later indicated because previous treatments had been unsuccessful. Surgical indication was based upon physical examination; varus deformity was present throughout the walking cycle and callosities were found on the lateral side of the foot, as well as shoe changes. Electromyography or walking analysis were not carried out.

Two different surgeons performed the operation according to the technique described by Green ${ }^{[5]}$.

Associated surgeries were carried out as needed according to associated deformities present in individual cases.

Informed consent was not required since the present study was retrospective and based upon review of medical records.

\section{RESULTS}

Results were evaluated through clinical criteria of deformity correction and need for orthoses following surgery. The following definitions were adopted: good result: corrected deformity and no need for orthosis; modest result: corrected deformity and need for orthosis (polypropylene splint) so as to make walking possible; poor result: residual deformity and need for posterior surgical correction. Good results were obtained in $67 \%$ of cases (8 feet -7 patients). Three feet (2 patients obtained modest results (25\%) and a poor result was obtained in 1 foot (8\%). No patient developed surgical complications (Table 1). 
rado do retropé. Após a realização de alongamento de isquiotibiais mediais, osteotomia tipo Dwyer e hemitransposição do tendão tibial anterior o pé tornou-se plantígrado, com melhora do padrão de marcha e ausência da necessidade do uso de órteses (bom resultado final). Nos casos com resultado regular, a necessidade de manutenção da órtese deveu-se à deformidade residual, não em eqüinovaro, mas em adução de antepé, ou falha na liberação do pé na fase de balanço, por insuficiência do músculo tibial anterior. Nos dois casos, com o uso da órtese, a melhora da marcha foi satisfatória, não havendo indicação para correções cirúrgicas subsequentes.

Dez pés necessitaram a realização de procedimentos concomitantes, visando a correção de deformidades associadas : alongamento do músculo gastrocnêmio pela técnica de Strayer, Vulpius ou Baker (9 pés), fasciotomia plantar (3 pés) e osteotomia de calcâneo pela técnica de Dwyer (3 pés). Somente um pé foi recebeu exclusivamente a hemitransposição do tendão do tibial posterior (Tabela 1).

\section{DISCUSSÃO}

A hiperatividade do músculo tibial posterior freqüentemente é responsável por deformidades em varo do pé em pacientes com PC. Segundo estudos de Green ${ }^{(5)}$, utilizando eletromiografia dinâmica e análise de marcha por vídeo, o músculo tibial posterior permanece continuadamente estimulado durante os ciclos da marcha em crianças portadoras desta deformidade. Quando avaliados através de análise laboratorial da marcha, pacientes com PC e deformidade em varo, mostram alterações da cinemática sagital. A amplitude de movimento do pé e tornozelo encontra-se diminuída na fase de apoio e ocorre predominantemente em flexão plantar e o ângulo de pré-posicionamento do pé encontra-se em varo ${ }^{(11)}$. Estas alterações dinâmicas da marcha, mais facilmente demonstradas e quantificadas pela análise laboratorial, devem ser notadas e criteriosamente avaliadas antes da indicação de tratamento ser formulada. É importante diferenciar clinicamente se a deformidade origina-se pela ação do tibial posterior, que comumente encontra-se tenso, gerando o desvio em varo do retropé freqüentemente associa-
In the case with poor result deforming forces acting upon the lower limb other than the tibialis posterior muscle were present and accounted for walking abnormality together with structured talipes varus. Following medial ischiotibial lengthening, Dwyer-type osteotomy, and split tibialis anterior tendon transfer the foot became plantigrade with improved walking pattern and no need for orthosis (a good final result). In cases with modest results the need for orthosis was due to residual deformity, not talipes equinovarus but adduction of the front foot or faulty release of the foot in the balance phase due to insufficiency of the tibialis anterior muscle. In both cases, walking pattern was improved with the use of orthosis and posterior surgical repairs were not required.

Concomitant surgeries were carried out to correct associated deformities of 10 feet, including lengthening of gastrocnemius muscle according the Strayer, Vulpius, or Baker technique (9 feet), plantar fasciotomy (3 feet), calcaneus osteotomy by Dwyer technique (3 feet). Split tibialis posterior tendon transfer was the sole surgery in one foot only (Table 1).

\section{DISCUSSION}

Hyperactivity of the tibialis posterior muscle is often responsible for talipes varus in patients with CP. According to studies carried out by Green ${ }^{[5]}$ using dynamic electromyography and video analysis of walking pattern, the tibialis posterior muscle is continuously stimulated during walking cycles in children with this deformity. Laboratory analysis of walking reveals changes in sagittal kinematics in patients with CP and talipes varus. Foot and ankle motion range is descreased during the support phase and predominantly appears with plantar flexion when foot prepositioning angle is in the varus position [11]. Dynamic changes in walking, more easily demonstrated and quantified by laboratory analysis, should be carefully investigated and recorded before therapy is considered. One must clinically establish whether deformity results from the tibialis posterior or anterior muscle action. When 
do ao eqüino, ou na ação alterada do músculo tibial anterior, onde geralmente a deformidade é em adução e supinação dinâmicas do pé. Em muitas situações, entretanto, não é possível descartar a espasticidade concomitante do músculo tibial anterior ${ }^{(8,11)}$. Nosso estudo não contou com a análise laboratorial da marcha na avaliação pré-operatória, como a maioria dos trabalhos publicados sobre esta técnica. O conhecimento da fisiopatologia das deformidades na paralisia cerebral espástica e um exame físico cuidadoso e completo, aliado à realização de vídeos do paciente, parecem ser suficientes para a indicação deste procedimento, idéia que também é compartilhada por outros autores ${ }^{(3,14)}$. A análise laboratorial da marcha é, contudo, uma importante ferramenta na avaliação de pacientes com paralisia cerebral. Pacientes com paralisia cerebral mista (que na nossa casuística não obtiveram bons resultado com o tratamento preliminar) e onde a avaliação clínica pode ser difícil e variável, talvez pudessem ser melhor avaliados e terem uma indicação cirúrgica diferente em um primeiro momento, com base em outras informações disponíveis pela análise laboratorial da marcha.

Vários relatos da literatura, apontam a hemitransposição do tendão do tibial posterior como técnica eficaz e segura para a correção da deformidade em varo dos pés espásticos. A hemitransposição do tendão do tibial posterior melhora os mecanismos da marcha, eliminando o apoio da borda lateral, permitindo o calcâneo tocar o solo primeiro, sem sobrecarga da coluna lateral e abolindo a necessidade do uso de órteses. Em um singular estudo com avaliação dos resultados utilizando a análise laboratorial de marcha, O'Byrne ${ }^{(11)}$ demonstrou objetivamente a melhora do alinhamento do retropé no plano sagital após a cirurgia, com 13 dos 16 pacientes operados obtendo excelentes resultados. Piazza et al. ${ }^{(12)}$ demonstraram em espécimes anatômicos que as hemitransferências dos tendões do tibial posterior e anterior reduzem os momentos de inversão da articulação subtalar de forma muito sensível, tornando estes procedimentos muito suscetíveis a erros técnicos, especialmente relacionados ao equilíbrio das tensões entre as porções medial e lateral dos tendões, demonstrando que obediência à técnica originalmente descrita é essencial para o obtenção de bons resultados.

Esta técnica é a que também demonstra baixo índice de complicações, como perda da correção ao longo do tempo e correções insuficientes ou excessivas evoluindo para pé valgo ou calcâneo. Fucs et al (3) relatou 90,24\% de bons resultados, Green ${ }^{(5)}, 1$ resultado insatisfatório em 16 pa-

cientes operados, Kling (8) relatando os resultados de 31 pacientes operados, mostrou 30 casos com resultados excelentes, 4, bons e 3, maus resultados. Nossa casuística mostra bons resultados em $67 \%$ dos casos e sem correções excessivas em valgo ou quaisquer outras complicações (Figura 1). the tibialis posterior muscle is involved, it is usually tense and produces varus shift of the hindfoot, often in association with talipes equinus. In contrast, when the tibialis anterior muscle is involved, deformity occurs with dynamic adduction and supination of the foot. However, in many situations, concomitant spasticity of the tibialis anterior muscle cannot be ruled out ${ }^{[8,11]}$. In the present study, laboratory analysis of walking was not carried out before surgery, as most published studies evaluating this technique. Knowledge of deformity physiopathology in spastic cerebral palsy and a careful and thorough physical examination together with videos of patients seem to suffice for indication of surgery, an idea shared by other authors ${ }^{[3,14]}$. Laboratory analysis of walking, however, is an important tool in the evaluation of patients with cerebral palsy. Patients with mixed cerebral palsy (in whom good results were not obtained with preliminary treatment) perhaps could be best evaluated and treated based upon data obtained by laboratory analysis of walking since clinical evaluation can be difficult in these cases.

Several reports consider split tibialis posterior tendon transfer a safe and effective technique for correction of spastic talipes varus. With this technique, walking mechanisms are improved and, lateral border support is eliminated, thus allowing calcaneus to be the first to come in contact with the floor with no lateral column load and no need for orthoses. In a singular study using laboratory analysis of walking, O'Byrne ${ }^{[11]}$ has objectively shown an improvement of hindfoot alignment in the sagittal plane following surgery with excellent results in 13 out of 16 patients. Using anatomical specimens Piazza et al. [12] have shown that split tibialis posterior and anterior tendon transfer substantially decreased inversions of the subtalar joint. As a result, these techniques are very susceptible to technical failures, specially those related to tension balance between the medial and lateral portions of tendons. This shows that good results are obtained only if the originally described technique is rigorously adopted.

This technique is also associated with a low complication rate, such as correction loss in the long run and overcorrections or undercorrections, resulting in talipes valgus or calcaneus. Fucs et al. ${ }^{[3]}$ reported good results in 90.24\%; Green ${ }^{[5]}$ reported one unsatisfactory result in 16 patients; Kling ${ }^{[8]}$ reported excellent results in 30 cases, good results in 4 and poor results in 3 out of 31 patients. The present study found good results in $67 \%$ of cases and no valgus overcorrection or other complications (Figure 1).

Modest results obtained in patients who still neeeded orthosis following surgery can be related to lack of active dorsiflexion 
Os resultados regulares, em que persistiu a necessidade do uso de órtese no pós-operatório podem ser vinculados, como em 2 pés operados, à falta de dorsiflexão ativa do pé, sendo o uso da mesma necessário a fim de facilitar o despregamento, fato também observado por Kling ${ }^{(8)}$. O'Byrne ${ }^{(11)}$ demonstrou que alguns de seus casos, em que não havia dorsiflexão ativa antes da cirurgia, o fizeram após a transferência. Em nosso estudo não pudemos observar este fato. No outro caso, o resultado regular, deveu-se à deformidade em adução dinâmica do pé, controlável pelo uso de órtese e um discreto grau de deformidade em varo residual, que possivelmente deveria ter sido tratado previamente através da realização de osteotomia do calcâneo. Este caso em particular apresentava paralisia cerebral do tipo misto (componente atetóide).

Os maus resultados após o emprego desta técnica descritos na literatura abrangem correção insuficiente, com excessivo varo do retropé, além da possibilidade de correção excessiva, com deformidade em valgo subseqüente. Autores como Synder ${ }^{(14)}$ e Fucs et al ${ }^{(3)}$ relataram em cada estudo, 3 casos com mau resultado, todos com deformidade residual em varo. Préoperatoriamente é importante que deformidades ósseas estruturadas sejam reconhecidas e tratadas adequadamente antes ou conjuntamente com a hemitransposição do tendão do tibial posterior, pois somente a cirurgia de partes moles é incapaz de corrigir tais deformidades. Entre nossos casos, deformidades ósseas estruturadas de retropé notadas no período pré-operatório foram corrigidas através de osteotomia do calcâneo, concomitantemente à transposição tendinosa. Nosso mau resultado deveu-se provavelmente a uma avaliação pré-operatória incorreta em um paciente distônico, em que possivelmente, devido às características próprias de variação do tônus muscular, a deformidade do pé originava-se muito mais em alterações do músculo tibial anterior e isquiotibiais do que no músculo tibial posterior. Além disso, neste caso, a deformidade óssea estruturada do retropé não foi adequadamente tratada na primeira intervenção. Posteriormente, com a realização de alongamento da musculatura isquiotibial medial, hemitransposição do tendão do tibial anterior e osteotomia de calcâneo o pé tornou-se plantígrado e livre de órteses. Nestes casos de dificuldade de avaliação pré-operatória a repetição do exame físico, a filmagem do paciente deambulando e, idealmente, a realização de análise laboratorial de marcha podem estar indicados. A presença de componentes distônicos ou de movimentos involuntários associados à espasticidade entretanto, não parecem ser, de acordo com a literatura, contra-indicação a esta técnica cirúrgica(7).

Grande parte dos autores que descreveu seus resultados com a técnica apontam a necessidade do alongamento simultâneo do tendão de Aquiles na maioria dos pacientes o que ocorreu em 11 de 12 pés do nosso estudo. Somente um paciente não necessitou de alongamento da musculatura flexora plantar, pois apresentava dorsiflexão de 10 graus com joelho em extensão e posição plantígrada do pé na fase de apoio. Mesmo com a afirmação de Green ${ }^{(5)}$, que a manutenção de metade do tendão do tibial posterior mantém a força flexora plantar, impedindo a deformidade em calcâneo, preferimos o alongamento da musculatura ao invés do alongamento tendinoso, visando diminuir a perda de força propulsora do tornozelo vinculada ao segundo $(3,4,5,8,11,14)$ of the foot, as seen in 2 feet; active dorsiflexion of the foot is required to make detachment easier, a fact also observed by Kling

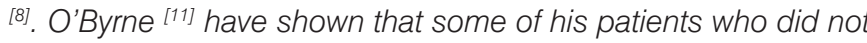
present active dorsiflexion before surgery developed this movement following transfer. In the present study this fact was not seen. In another case a modest result was due to a foot deformity in dynamic adduction that could be managed by an orthosis, and to a mild residual deformity in varus position that should be treated through calcaneus osteotomy in advance. This individual patient had mixed cerebral palsy (athetoid component).

According to literature poor results associated with this technique include undercorrections with excessive varus hindfoot as well as overcorrection resulting in valgus foot. Synder ${ }^{[14]}$ and Fucs et al. ${ }^{[3]}$ among others reported a poor result in 3 cases in each study, all of them with residual varus foot. Structured bone deformities must be identified before surgery and can be adequately treated before or concomitantly with split tibialis posterior tendon since soft tissue surgery only is not able to correct such deformities. In the present study structured bone deformities of the hindfoot diagnosed before surgery were treated with calcaneus osteotomy during tendon transfer.

The poor result seen in the present study was probably due to an incorrect preoperative evaluation in one dystonic patient. In this case, due to peculiar characteristics of muscular tonus changes, the foot deformity was due to changes in the tibialis anterior and ischiotibial muscles and not to changes in tibialis posterior muscle. In addition, in this case the structured bone deformity of hindfoot was not adequately treated during first surgery. With lengthening of medial ischiotibial musculature, split tibialis anterior tendon transfer, and calcaneus osteotomy, the foot became plantigrade, orthosis being not required.

In cases where preoperative evaluation is difficult, a repeated physical examination, recording of walking, and ideally laboratory analysis of walking can be indicated. According to literature dystonic components or involuntary movements associated with spasticity do not contraindicate the use of this technique ${ }^{[7]}$.

Several authors who described their results with the use of this technique have emphasized the need for simultaneous lengthening of Achilles tendon in the majority of patients.

This was needed in 11 out of 12 feet in our study. Lengthening of the plantar flexor musculature was not needed in one patient since he had 10-degree dorsiflexion with extended knee and plantigrade foot in the support phase.

Although Green ${ }^{[5]}$ stated that the maintenance of half of the tibialis posterior tendon preserves the plantar flexor force, thus preventing calcaneus deformity, we decided to lengthen musculature and not tendons because a decreased loss of propulsive force of the ankle associated with the latter was desirable $[3,4,5,8,11,14]$. 


\section{CONCLUSÃO}

A hemitransposição do tendão do tibial posterior no tratamento do pé varo espástico fornece bons resultados na correção desta deformidade. Para a correção de deformidade em eqüino concomitante, existe necessidade de realização de alongamento de músculos flexores plantares na maioria dos casos. Deformidades ósseas estruturadas devem ser reconhecidas e tratadas adequadamente. Avaliação clínica cuidadosa antes da cirurgia é fundamental, visando determinar os componentes anormais da marcha .

\section{CONCLUSION}

Split tibialis posterior tendon transfer in the management of the spastic talipes varus leads to good results as far as correction of this deformity is concerned. For concomitant correction of talipes equinus, lengthening of plantar flexor muscles is needed in the majority of cases. Structured bone deformities must be identified and adequately treated. Careful clinical evaluation before surgery is essential to define abnormal walking components.

\section{REFERÊNCIAS BIBLIOGRÁFICAS}

1. Banks HH. The management of spastic deformities of the foot and ankle. Clin Orthop 122:70-76, 1977.

2. Baker LD, Hill LM. Foot alignement in cerebral palsy in cerebral palsy patient. J Bone Joint Surg Am 46:1-15, 1964.

3. Fucs PMB, Kertzman PF, Svartman C. Tratamento do pé varo espástico da paralisia cerebral pela técnica da transferência do hemitendão do tibial posterior. Rev Bras Ortop 32:17-20, 1997.

4. Gage JR. Cerebral-palsied gait. In: Gait analysis in cerebral palsy. New York: Mac Keith Press, 1991. p.109-110.

5. Green NE. Split posterior tibial tendon transfer in spastic cerebral palsy. J Bone Joint Surg Am 65:748-754, 1983.

6. Johnson WL, Lester EL. Transposition of the posterior tibial tendon. Clin Orthop 245:223-227, 1989

7. Kagaya H. Split posterior tibial tendon transfer for varus deformity of hindfoot. Clin Orthop 323:254-260, 1996.
8. Kling TF. Split posterior tibial tendon transfer in children with cerebral spastic paralysis and equinovarus deformity. J Bone Joint Surg Am 67:186-194, 1985.

9. Mousny M, Allington N. Botulinum $A$ in the treatment of equinus dynamic spasticity in children with cerebral palsy. Preliminary study. Rev Chir Orthop 85:156-163, 1999

10. Mulier T. Split posterior tibial transfer through the interosseus membrane in spastic equinovarus deformity. Foot Ankle Int 16:754-759, 1995

11. O'Byrne JM. Split tibialis posterior tendon transfer in the treatment of spastic equinovarus foot. J Pediatr Orthop 17:481-485, 1997.

12. Piazza SJ, Adamson RL, Sanders JO, Sharkey NA. Change in muscle moment arms following split tendon transfer of tibialis anterior and tibialis posterior. Gait Posture 14:271-278, 2001.

13. Root L. Varus and valgus foot in cerebral palsy and its management. Foot Ankle 4:174-179, 1984.

14. Synder M. Split tibialis posterior tendon transfer and tendo-Achilles lengthening for spastic equinovarus feet. J Pediatr Orthop 13:20-23, 1993. 